\title{
Varietal Evaluation Studies in Cucumber under Prayagraj Agro-Climatic Condition (Cucumis sativus L.)
}

\author{
Nagana Boyana Prathyusha* and Devi Singh \\ Department of Horticulture, Naini Agricultural Institute, SHUATS, \\ Prayagraj, Uttar Pradesh, India \\ *Corresponding author
}

\begin{abstract}
A B S T R A C T
Eleven cucumber genotypes were evaluated at SHUATS, Prayagraj in randomized block esign with three replications quality during kharif seson-2019 for growth, yield and fruit traits. The genotype Manasa gave maximum mean value for number of fruits per vine (9.54), fruit weight (142.4), fruit yield (1.36), number of branches per vine (8.35) yield (40.79),TSS(4.76) Vitamin "C" (7.24 number of female flower per vine (27.35) minimum node number at which first female flower appears (7.51) was observed in same genotype, maximum numbers of male flowers per vine in genotype Laxmi (32.71) maximum length has been found in Laxmi (6.85) Minimum days were recorded for first Appearance of male flower in Manasa (37.60) Minimum node number at which First male flowers found in Laxmi (4.10). The genotype Laxmi has taken minimum (45.80) days to first harvesting followed by IETCUCUVAR-4 (50.45) Laxmi was found superior based on overall performance in terms of growth, yield, quality \& Economic returns. The highest cost benefit ratio (2.13) was found for cucumber in genotype Manasa under Prayagraj Agroclimate condition.
\end{abstract}

Keywords

Cucumis sativus, $L$, Evaluation, TSS,

Vitamin C

Article Info

Accepted:

07 October 2020

Available Online:

10 November 2020

\section{Introduction}

Cucumber (Cucumis sativus L.) is one of the most popular vegetable belong to the family Cucurbitaceae, with a chromosome number $2 n=14$. Botanically all cucurbits are 'Pepo' and belongs to family cucurbitaceae. Cucurbits are the largest group of summer season vegetables and extensively grown in tropical, subtropical and milder zones of India. Cucurbits have been important to man as a source of food and utensils since the down civilization. Cucumber (Cucumis sativus L.) is a widely cultivated plant in the gourd family Cucurbitaceous. It is a creeping vine that bears cylindrical fruits that are used as culinary vegetables. The cucumber is originally from Southern Asia, but now grows on most continents. Many different varieties are traded on the global market Rajawat et al., (2017).

The family cucurbitaceae is moderately large one, comprising about 117 genera and 825 species (Jeffery, 1983). It includes large number of vegetables such as cucumber, pumpkins, gourds and melons. Cucumber (Cucumis sativus L.) is one of the oldest 
amongst the cultivated vegetable crops and has been found in cultivation since 3000 to 4000 years.

It is an ideal summer vegetable crop chiefly grown in India as well as in the world for its edible tender fruits, preferred as salad ingredient, pickles, desert fruit and as a cooked vegetable. Cucumber has got cooling effect, so in the eastern countries, fruits are often used as cooling vegetable. Cucumber is considered as fourth most important vegetable crop after tomato, cabbage and onion.

Cucumber is considered as fourth most important vegetable crop after tomato, cabbage and onion. Cucumber is used for different purpose like as salad, table purpose and pickling but mostly used as salad purpose. The fruit of cucumber is said to have cooling effect, prevents constipation and checks jaundice and indigestion. It contains $(96.3 \mathrm{~g})$ water, $(0.4 \mathrm{~g})$ protein, $(0.1 \mathrm{~g})$ fat, $(0.3 \mathrm{~g})$ minerals, $(0.4 \mathrm{~g})$ fibre, $(2.5 \mathrm{~g})$ carbohydrate, (13Kcal) energy, (10mg) calcium, (25mg) phosphorus, (1.5mg)iron, $(0.33 \mathrm{mg})$ thiamine, (0.2mg) niacin, (7mg) vitamin ' $\mathrm{C}$ ' per $(100 \mathrm{~g})$ edible portion (Gopalan et al., 1982).

Cucumber is a commonly used salad vegetable and a source of a variety of conventional nutrients and antioxidants. It is widely used for various skin problems including swelling under the eyes and sunburn, as it promotes refreshing, cooling, healing, soothing, and anti-itching effect to irritated skin Chuyaku (1985). Several pharmacological activities including the antioxidant, antiwrinkle, antimicrobial, antidiabetic, and hypolipidemic potentials have been reported with this plant. One of the antioxidants found in cucumber has been identified as an essential component in organism's defense mechanism against oxidative stress Lee et al., (2003).
With the large vegetarian population in India, the production of vegetables needs to be greatly increased. Though the Central and State Governments have taken some steps for increasing production of vegetables crops the research activities are falling short to the requirement of the various vegetables grown in India, cucumber has high place in the diet as a rich source of carbohydrates, as a breakfast fruit and as ingredient of salads.

The proportion of male and female flowers affects the yield and the cultivars having more pistillate flowers will set more fruits resulting in higher yields. Although cucumber is grown throughout the world, evaluations of different cultivars have been conducted in various countries. Shetty and Wehner (1998) studied 18 cucumber cultivars on trellis and flatbeds.

Majority of farmer are still growing local cultivar. There is lack of suitable cultivars in Allahabad agro-climate condition. Therefore, there is need to find out most suitable genotype in terms of growth, yield and quality of cucumber under Allahabad agro-climate conditions. There is considerable scope and demand for high yielding and good quality cultivars Rajawat et al., (2017).

\section{Materials and Methods}

The present investigation was carried out during the month of August 2019 to October 2019 at Vegetable Research Farm. Department of Horticulture, Naini Agriculture Institute, Sam Higginbottom University of Agriculture, Technology and Sciences, Prayagraj (U.P.), India. Prayagraj has a subtropical and semi-arid climatic condition, south-eastern part of Uttar Pradesh prevails with both extremes of temperature during the crop season, i.e. $13^{0} \mathrm{C}$ to $45^{\circ} \mathrm{C}$. The average rainfall in this area is about $1100 \mathrm{~mm}$ per annum. 
The soils were characterized as sandy loam in texture with $\mathrm{pH} 6.8$ analyzed using glass electrode $\mathrm{pH}$ (Richards, 1954), available $\mathrm{N}$ $0.092 \%$ Modified Kjeldal's method (Jackson, 1967), available P $0.80 \%$, analyzed Bicarbonate extractable ' $\mathrm{P}$ ' and development of blue colour (Jackson, 1967), available K $0.54 \%$ analyzed by Neutral normal ammonium acetate method (Jackson, 1967)

The experiment was laid out in randomized block design with threereplicationon24-072019.Thesowingwasdoneonraisedbedmethod withspacingof $1.0 \mathrm{~m}$ and $1.5 \mathrm{~m}$, plant to plant and row to row, respectively, each plot with 4 plants. Adopting the recommended cultivation practices for raising a healthy crop and used the trellis system for vines climbing. Data were recorded on all the important characters pertaining to the present study.

For growth and floral attributes, Days to first appearance of male flower of four observational vines were counted from sowing date to first appearance of male flower, Days to first appearance of female flower of four observational vines were counted from sowing date to first appearance of female flower and total value was average out in days, Node number at which first male flower appeared in individual vine (selected) of a pot were recorded as node number to first male flower and average was calculated over the four vines, Node number of which first female flower appeared in individual vine (selected) of a plot were recorded as node number to first female flower and average was calculated over the flourvines, Number of male flowers of all the four vines from each plot were counted and average number of male flowers per vine was calculated, Number of female flowers of all the four vines from each plot were counted and average number of female flowers per vine was calculated The vine length of the four individual vines were measured with the help of meter tape after 90 days of sowing in centimeter and average was calculated, The number of branches for four observational vines were counted at the time of final harvesting and mean number of branches per vine was worked out.

For yield attributes, Number of fruits harvested from the observational vines at different pickings were added and mean number of per vine harvested during the seasons was worked out, Fruit diameter $(\mathrm{cm})$ of four randomly selected fruits was measured in $\mathrm{cm}$ and average diameter was calculated, Fruit length (cm) was measured from peduncle end of fruit to blossom scar point with help of measuring tape, Fruit weight (g) of harvested fruits measured with the help of weighing balance in gram, Number of days taken from the date of sowing to the date of first harvest of the edible green fruits in a plot was recorded as days to first fruit harvest for a particular hybrid, The total edible green fruit yield overall the picking was recorded for each plot and yield expressed as per vine by dividing number of vines. At first total fruit yield was counted per plot then it was converted into tons per hectare.

For quality attributes, Total soluble solid was determined with the help of Erma hand refract meter (0.32 range) averaged and analyzed, for Vitamin , $\mathrm{C}^{\text {ce }}(\mathrm{mg} / \mathrm{100 \textrm {g }})$ of fruit juice was filtered through muslin cloth $10 \mathrm{ml}(\mathrm{W})$ of the juice was taken with the help of a pipette in $100 \mathrm{ml}$ volumetric flask and the volume $\left(\mathrm{V}_{1}\right)$ was made up with $1.0 \%$ oxalic acid solution. The flask was then shaken well. The juice was then filtered known quality $\left(\mathrm{V}_{2}\right)$ of the solution was titrate against standard dye (V) solution till a faint pink color appeared and persisted for 15 seconds and calculated with the formula.

The data from the experiments were analyzed statistically, wherever treatment differences were found significant, the critical differences 
were worked out at 5\% level of probability $(P=0.05)$.

\section{Results and Discussion}

\section{Growth parameters}

Varieties minimum days were recorded for first appearance of male flower in hybrid Laxmi F-1 (32.71 days), followed by Priya (33.52), Larven (34.22), IET2018/ CUCUVAR - 4(34.24), IET2018/ CUCUVAR-3 (34.84), Raj (35.59) and IET2018/ICUCVAR-2 (35.68). The maximum days to first appearance of male flower were found in Sunbeej (38.18 days). The days of first appearance of male flower plays an important role in deciding the earliness or lateness of crop in general.

Minimum days were recorded to first appearance of female flower is Laxmi $-\mathrm{F} 1$ (36.02 days), followed by Priya (36.87), Larven (37.24), IET2018/CUCUVAR-3 (38.57), Raj (38.66) and IET2018/CUCUVAR-4 (39.57). Maximum days were recorded to first appearance of female flower with Sunbeej (42.43 days). The number of days from sowing of first appearance of female flower is an important character that indicates earliness or lateness of the crop in general. Similar findings were reported by Sharma and Bhattarai (2006) and Patel et al., (2013).

Minimum node number at which first male flower was found is in Laxmi $-\mathrm{F} 1$ (4.10 node), followed by Manish (5.20), IET2018/CUCUVAR-4 (5.19), IET2018/ CUCUVAR-3 (5.55) and IET2018/ ICUCVAR-2 (5.69). Maximum node number at which first male flower appears in Sunbeej (7.67 node). The variation in node number at which first male flower appears might have been due to specific genetic makeup of different Varieties prevailing environment condition. Similar findings were reported by Sharma and Bhattarai (2006), Bairagi et al., (2005) and Maurya et al., (2004) in Bottlegourd.

Appearance of node number at which first female flower was appeared minimum with Laxmi-F1 (5.59 node) followed by Manish (6.43), IET2018/ICUCVAR-2 (6.78), IET2018/CUCUVAR-3 (6.78) and IET2018 /CUCUVAR-4 (6.53). Maximum node number at which female flower had been shown as Sunbeej (9.62). The variation in node number at which first female flower appears might have been due to specific genetic makeup of different Varieties and prevailing environmental condition. Similar findings were reported by Sharma and Bhattarai (2006) and Bairagi et al., (2005). (Table 1 and 2; Figure 1). Similar results have been reported by Patel et al., (2013).

Maximum number of male flowers per vine in hybrid Laxmi -F1 (213.17), followed by IET2018/ ICUCVAR-2 (198.46), IET2018/ CUCUVAR-3 (199.74) and IET2018/ CUCUVAR-4 (188.41). Minimum number of male flowers per vine was found in Sunbeej (128.59). The variation in number of male flowers might have been due to their genetic nature, environmental factor, hormonal factor and vigour of crop. Similar results have been reported by Solanki and Seth (1980), Sahni et al., (1987) and Rastogi et al., (1990). Similar results have been reported by Patel et al., (2013).

Number of female flowers per vine differed significantly. Maximum number of female flowers in hybrid Laxmi -F1 (33.74) flowed by Manish (32.34), Raj (30.50), Larven (31.45) and Royal Seeds (30.52). The varieties Sunbeej (26.72) shown less number of female flowers. Significant differences were recorded among the Varieties with regard to vine length. Maximum vine length 
has been found Laxmi -F1 (263.43) followed by IET2018/ICUCVAR- 2 (248.33), IET2018/ CUCUVAR-3 (255.69), IET2018/ CUCUVAR-4 (263.27) and Manish (258.51). The varieties Sunbeej had minimum vine length $(210.58 \mathrm{~cm})$. The variation in vine length might have been due to specific genetic makeup of different Varieties, inherent properties, environmental factor, hormonal factor and vigor of the crop. The variation of the vine length in cucumber has also been reported by Solanki and Seth (1980).

Table.1

\begin{tabular}{|c|c|c|c|c|c|c|c|c|c|}
\hline Treatment & Varieties & $\begin{array}{l}\text { Days to first } \\
\text { appearance } \\
\text { of male } \\
\text { flower }\end{array}$ & $\begin{array}{c}\text { Days to } \\
\text { first } \\
\text { appearance } \\
\text { of female } \\
\text { flower }\end{array}$ & $\begin{array}{c}\text { Node } \\
\text { number at } \\
\text { which first } \\
\text { male flower } \\
\text { appears }\end{array}$ & $\begin{array}{c}\text { Node } \\
\text { number at } \\
\text { which first } \\
\text { female flower } \\
\text { appears }\end{array}$ & $\begin{array}{l}\text { No. of } \\
\text { male } \\
\text { flowers } \\
\text { per } \\
\text { vine }\end{array}$ & $\begin{array}{c}\text { No. of } \\
\text { female } \\
\text { flowers } \\
\text { per } \\
\text { vine }\end{array}$ & $\begin{array}{l}\text { Vine } \\
\text { length } \\
(\mathrm{cm})\end{array}$ & $\begin{array}{c}\begin{array}{c}\text { Number } \\
\text { of } \\
\text { branches }\end{array} \\
\text { per vine }\end{array}$ \\
\hline $\mathbf{T}_{1}$ & Royal Seeds & 36.84 & 41.56 & 6.81 & 7.47 & 170.36 & 30.52 & 223.53 & 7.61 \\
\hline $\mathbf{T}_{2}$ & Sunbeej & 38.18 & 42.43 & 7.67 & 9.62 & 128.59 & 26.72 & 210.58 & 5.45 \\
\hline$T_{3}$ & Manasa & 37.6 & 40.5 & 6.14 & 7.51 & 136.8 & 27.35 & 228.45 & 8.35 \\
\hline $\mathbf{T}_{4}$ & $\begin{array}{c}\text { IET2018/ } \\
\text { ICUCVAR-2 }\end{array}$ & 35.68 & 40.56 & 5.69 & 6.78 & 198.46 & 28.55 & 248.33 & 9.18 \\
\hline $\mathbf{T}_{5}$ & $\begin{array}{c}\text { IET2018/ } \\
\text { CUCUVAR-3 }\end{array}$ & 34.84 & 38.57 & 5.55 & 6.78 & 199.74 & 27.94 & 255.69 & 9.47 \\
\hline $\mathbf{T}_{6}$ & $\begin{array}{c}\text { IET2018/ } \\
\text { CUCUVAR-4 }\end{array}$ & 34.24 & 39.57 & 5.19 & 6.53 & 188.41 & 30.46 & 263.27 & 9.31 \\
\hline $\mathbf{T}_{7}$ & Priya & 33.52 & 36.87 & 6.25 & 7.4 & 148.41 & 29.44 & 220.54 & 10.51 \\
\hline $\mathbf{T}_{8}$ & Larven & 34.22 & 37.24 & 7.52 & 7.25 & 163.3 & 31.45 & 232.47 & 11.42 \\
\hline$T_{9}$ & Laxmi -F1 & 32.71 & 36.02 & 4.1 & 5.59 & 213.17 & 33.74 & 263.43 & 12.59 \\
\hline T10 & Raj & 35.59 & 38.66 & 7.38 & 8.62 & 149.2 & 30.5 & 237.9 & 8.47 \\
\hline \multirow[t]{3}{*}{ T11 } & Manish & 36.79 & 40.34 & 5.2 & 6.43 & 174.02 & 32.34 & 258.51 & 8.61 \\
\hline & S. Ed. $( \pm)$ & 0.168 & 1.082 & 0.185 & 0.369 & 0.955 & 0.669 & 0.293 & 0.406 \\
\hline & C. D. at $5 \%$ & 0.08 & 0.519 & 0.089 & 0.177 & 0.458 & 0.321 & 0.14 & 0.195 \\
\hline
\end{tabular}

Table.2

\begin{tabular}{|c|c|c|c|c|c|c|c|c|c|c|}
\hline Treatment & Varieties & $\begin{array}{l}\text { Number } \\
\text { of fruits } \\
\text { per vine }\end{array}$ & $\begin{array}{c}\text { Fruit } \\
\text { diameter } \\
(\mathrm{cm})\end{array}$ & $\begin{array}{l}\text { Fruit } \\
\text { length } \\
\text { (cm) }\end{array}$ & $\begin{array}{c}\text { Fruit } \\
\text { weight } \\
\text { (g) }\end{array}$ & $\begin{array}{l}\text { Days to first } \\
\text { fruit } \\
\text { harvest }\end{array}$ & $\begin{array}{c}\text { Fruit } \\
\text { yield per } \\
\text { vine }(\mathbf{k g})\end{array}$ & $\begin{array}{c}\text { Fruit } \\
\text { yield }(t \\
\left.\text { ha }^{-1}\right)\end{array}$ & $\begin{array}{l}\text { Total soluble } \\
\text { solid }\left({ }^{\circ} \text { Brix) }\right.\end{array}$ & $\begin{array}{c}\text { Vitamin C } \\
\text { (mg / 100 } \\
\text { g) }\end{array}$ \\
\hline$T_{1}$ & Royal Seeds & 10.52 & 4.38 & 13.58 & 148.61 & 51.51 & 1.56 & 46.9 & 4.34 & 6.1 \\
\hline $\mathbf{T}_{2}$ & Sunbeej & 7.76 & 3.66 & 12.52 & 138.45 & 52.55 & 1.07 & 32.24 & 4.02 & 5.85 \\
\hline $\mathbf{T}_{3}$ & Manasa & 9.54 & 4.42 & 13.21 & 142.48 & 50.32 & 1.36 & 40.79 & 4.76 & 7.24 \\
\hline$T_{4}$ & $\begin{array}{c}\text { IET2018/ } \\
\text { ICUCVAR-2 }\end{array}$ & 14.64 & 5.24 & 16.77 & 158.49 & 46.83 & 2.32 & 69.63 & 5.18 & 6.71 \\
\hline $\mathbf{T}_{5}$ & $\begin{array}{c}\text { IET2018/ } \\
\text { CUCUVAR-3 }\end{array}$ & 13.36 & 5.68 & 16.18 & 151.64 & 47.58 & 2.03 & 60.79 & 4.7 & 6.44 \\
\hline$T_{6}$ & $\begin{array}{c}\text { IET2018/ } \\
\text { CUCUVAR-4 }\end{array}$ & 15.32 & 5.44 & 16.41 & 162.28 & 50.45 & 2.49 & 74.57 & 4.47 & 6.24 \\
\hline $\mathbf{T}_{7}$ & Priya & 8.74 & 6.29 & 14.75 & 142.37 & 48.44 & 1.24 & 37.34 & 5.32 & 5.69 \\
\hline $\mathbf{T}_{8}$ & Larven & 16.78 & 4.8 & 12.57 & 149.61 & 46.77 & 2.51 & 75.31 & 5.1 & 5.46 \\
\hline$T_{9}$ & Laxmi -F1 & 18.51 & 6.85 & 17.53 & 163.45 & 45.8 & 3.03 & 90.77 & 5.77 & 7.56 \\
\hline T10 & Raj & 11.74 & 4.86 & 13.58 & 140.56 & 47.79 & 1.65 & 49.52 & 5.26 & 7.08 \\
\hline \multirow[t]{3}{*}{ T11 } & Manish & 13.5 & 4.28 & 12.52 & 160.52 & 47.53 & 2.17 & 65 & 5.37 & 6.54 \\
\hline & S. Ed. $( \pm)$ & 0.287 & 0.276 & 0.229 & 0.162 & 0.213 & 0.043 & 1.293 & 0.292 & 0.408 \\
\hline & C. D. at $5 \%$ & 0.138 & 0.132 & 0.11 & 0.078 & 0.102 & 0.021 & 0.62 & 0.14 & 0.196 \\
\hline
\end{tabular}


Fig. 1

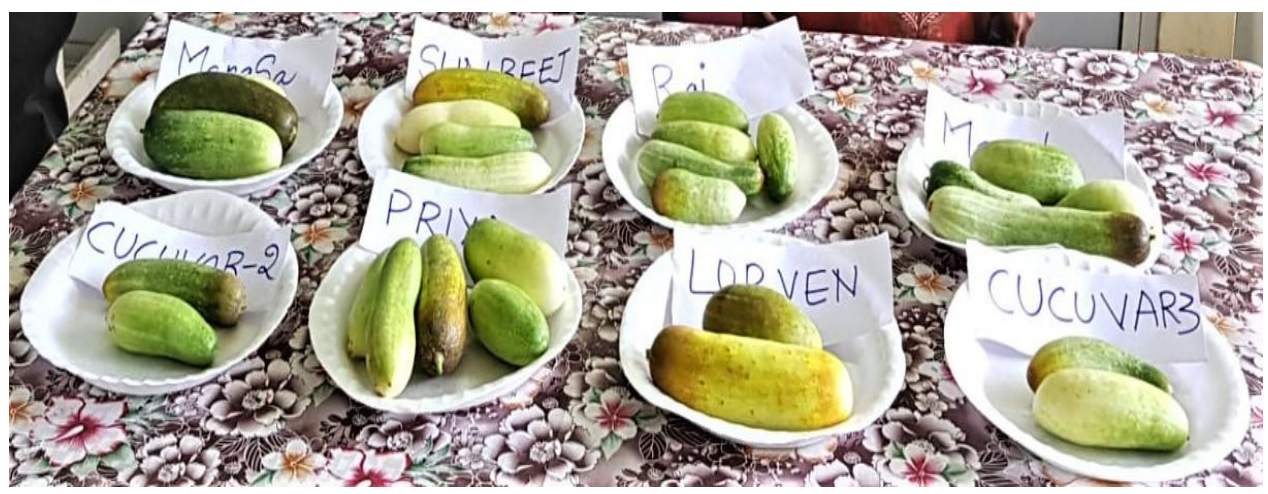

Maximum number of branches per vine was recorded in hybrid Laxmi -F1 (12.59) followed by Larven (11.42), Priya (10.51), IET2018/CUCUVAR-3 (9.47), IET2018/ CUCUVAR-4 (9.31) and IET2018 /ICUCVAR-2 (9.18). While the lowest number of branches per vine was recorded in Sunbeej (5.45).The variation in number of branches per vine might have been due to its own genetic makeup and also due to vine length, internodal length, hormonal factor and environmental factor also. The variation of the number of branches in cucumber have also been reported by Sharma and Bhattarai (2006), Sahni et al., (1987) and Bairagi et al., (2005).

The maximum number of fruits per vine were found in hybrid Laxmi -F1 (18.51), followed by Larven (16.78), IET2018/ICUCVAR-2 (14.64), IET2018/CUCUVAR-3 (13.36), IET2018/CUCUVAR-4 (15.32) and Manish (13.50).

The lowest number of fruits was recorded in Sunbeej (7.76). The fruits per vine is one of the major factor for deciding the yield of the crop. The variation in fruits per vine might have been due to sex ratio, fruit set percentage, genetic nature and their response to varying environmental conditions. Similar results have been reported by Srivastava and Srivastava (1976), Singh et al., (1977), Prasad (1985), Aviles Rodriguez et al., (1990),
Grimstad (1990) and Singh et al., (1996).

\section{Yield}

The Varieties differed significantly with regard to fruit diameter. The maximum fruit diameter was found in Laxmi -F1 (6.85), followed by Priya (6.29), IET2018/ ICUCVAR-2 (5.24), IET2018/CUCUVAR-3 (5.68) and IET2018/CUCUVAR-4 (5.44). The minimum fruit diameter was found in Sunbeej (3.66).

Increasing of fruit yield is mostly influenced by fruit diameter. The fruit diameter will be high than automatically fruit yield will be also high. The variation in fruit diameter, might have been due to genetic factor, environmental factor, hormonal factor and vigour of the crop. Similar results have been reported by Sahni et al., (1987), Ahmed et al., (2004) and Badgujar and More (2004).

The maximum fruit length was found with Laxmi -F1 (17.53) followed by IET2018/ICUCVAR-2 (16.77), IET2018/CUCUVAR-3 (16.18) and IET2018/CUCUVAR-4(16.41). The minimum fruit length was recorded with Sunbeej (12.52). Fruit yield is also depend on fruit length, increasing fruit length will increase fruit yield. The variation in fruit length, might have been due to genetic nature, environmental factor, hormonal factor and 
vigour of crop. Similar results have been reported by Joshi et al., (1981), AvilesRodriguez et al., (1990) and Rastogi et al., (1990).

The highest fruit weight were recorded in Laxmi -F1 (163.45), followed by IET2018/ICUCVAR-2 (158.49), IET2018/ CUCUVAR-3 (151.64), IET2018 /CUCUVAR-4 (162.28) and Manish (160.52) and the lowest fruit weight was found in Sunbeej (138.45).The higher fruit diameter and higher length result into higher fruit weight. The highest fruit weight in Garima Super may be due to its hybrid vigour and adoptability to Allahabad agro-climatic conditions. Similar results have been reported by Kallo et al., (1983), Prasad (1985) and Chen et al., (1994).

The hybrid Laxmi -F1 has taken minimum (45.80 days) to first harvesting followed by Larven (46.77), IET2018/ICUCVAR-2 (46.83), Manish (47.53), IET2018/ CUCUVAR-3(47.58) and Raj (47.79). Sunbeej (52.55days) has been taken very much time to first harvesting. The variation in days to first fruit harvesting might have been due to genetic factor, environmental factor, hormonal factor and vigour of crop. Similar results have been reported by Prasad (1985), Paner (1995) and Howalder et al., (1999).

The Varieties differed significantly with regard to yield per vine. The maximum fruit yield $(\mathrm{kg})$ per vine was recorded in Laxmi $-\mathrm{F} 1$ (3.03kg) followed by IET2018/ICUCVAR-2 (2.32), IET2018/CUCUVAR-3 (2.03) and IET2018/CUCUVAR-4 (2.49). The lowest fruit yield per vine was found in Sunbeej (1.07kg).

The significant variation in yield per vine might have been due to fruit set percentage, fruit length, number of fruit per vine, fruit weight and fruit width, genetic nature, environmental factor and vigour of the crop.
These findings were supported by Srivasvata and Srivastava (1976), Singh et al., (1996) and Hawlader et al., (1991).

The maximum yield (tonnes / ha) was recorded in Laxmi -F1 (90.77) followed by IET2018/ICUCVAR-2 (69.63), IET2018/ CUCUVAR-3 (60.79), IET2018/CUCUVAR4 (74.57), Larven (75.31) and Manish (65.00). The lowest fruit yield per vine was found in Sunbeej (32.24) and were also supported by Grebensickov (1979), Sahni et al., (1987), Rastogi et al., (1990), Paner (1995) and Sharma and Bhattarai (2006).

The maximum TSS value was found in Laxmi -F1 (5.77) followed by Manish (5.37), Raj (5.26), Priya (5.32), IET2018/ICUCVAR-2 (5.18) and Larven (5.10). The minimum TSS value was found with Sunbeej (4.02). The higher TSS value in Laxmi -F1 may be due to its inherent characteristics. Similar estimates for this character were also recorded in different genotypes in cucumber (Kumar et al., 2016).

The maximum vitamin ' $\mathrm{C}$ ' $\mathrm{mg} / 100 \mathrm{~g}$ recorded in Laxmi -F1 (7.56) followed by Raj (7.08), Manasa (7.24), IET2018/ICUCVAR-2 (6.71), IET2018/CUCUVAR-3 (6.44) and IET2018/CUCUVAR-4(6.24). The lowest vitamin ' $\mathrm{C}$ ' $\mathrm{mg} / 100 \mathrm{~g}$ was found with Sunbeej $(5.85 \mathrm{mg})$. Generally, high ascorbic acid content would increase the nutritive value of cucumbers, which would help better retention of color and flavor. Similar estimates for this character were also recorded in different genotypes in cucumber (Kumar et al., 2016).

\section{References}

Ahmed, Maqsood; Hamid, Abdul and Zarqa, Akbar (2004). Growth and Yield Performance of Six Cucumber (Cucumis sativus L.). Cultivars Under Agro- Climatic Conditions of Rawalakot, Azad Jammu and 
Kashmir. International J. Agri. \& Bio. 1560-8530/06-2-396-399

Aviles-Rodriguez, L.N.; Caraballo, E. and Fornaris-Rullan, G. (1990). An evaluation of 10 cucumber (Cucumis sativa L.) cultivars in southern PuertoRico. J. Agri. the Univ. of Puerto Rico. 74(4):461-463.

Bairagi, S.K., Ram, H.H., Singh D.K. and Maurya, S.K. 2005. Exploitation of hybrid vigor for yield and attributing traits in cucumber. Ind. J. Hort. 62 (1):41-45.

Badgujar CD, More TA. (2004). Off season performance of selected tropical gynocecious cucumber hybrids grown under different regimes. South. Ind. Horti. J 2004; 52(1/6):97-103.

Chen Xuehao; Cao Peishing and Xu Quiang (1994). Genetic Correlation and path coefficient analysis of yield components, in cucumber in Beijing, China Adv. Hort., pp 249-251.

Chuyaku DD. (1985). Shanghai Technology. Shogakukan Press; Tokyo; 1985.

Grimstad, S.O.(1990). Evaluation trials of greenhouse cucumbers. [Norwegian] Gartneryrket. 80 (21): 16-18.

Gopalan, C., Shastri, B. V. R. and Balasubramaniam, S. C. (1982). Nutritive value of Indian food, Indian Council of Medical Res., Hyderabad, National Institute of Nutrition, 18: 251-253.

Jackson, M.L. (1967). Soil Chemical Analysis Prentice Hall Inc. Englewood cliffs, New Jersy, 49.

Jeffery, C. (1983). Proc. Conference on the Biology and Chemistry of Cucurbitaceae, Cornell University, Ithaca, New York, August, pp. 141145.

Joshi, S., Joshi, M.C., Singh, B. and Vishoni, A. K. (1981). Genotypic and phenotypic variability in cucumber (Cucumis sativus L.). Veg. Sci. 8 (20):
114-119.

Kalloo, G., Dixit, J. and Sithu, A.S. (1983). Studies on genetic variability characters association in muskmelon (Cucumis melo L.) Ind. J. Hort. 40 (1 \& 21): 79-85

Lee HS, Kwon EJ, Kwon SY, Jeong YJ, Lee EM, Jo MH, Kwak SS. (2003) Transgenic cucumber fruits that produce elevated level of an anti-aging superoxide dismutase. Molecular Breeding; 11(3):213-220.

Maurya, S.K., Ram, H. H. and Singh, D.K. (2004). Combining ability analysis in bottle gourd. Prog. Hort. 36 (1): 6772.

Patel, J. K.; Vijay Bahadur; Devi Singh; Prasad, V. M.; Rangare, S. B. 2013. Performance of cucumber (Cucumis sativus L.) hybrids in agro-climatic conditions of Allahabad. HortFlora Res. Spectrum, 2(1):50-55.

Rajawat Kuldeep Singh, John Philip Collis., Gajendra Singh., Jalam Singh, and Ritu Rani Minz. (2017). Varietal Evaluation Studies in Cucumber (Cucumis sativus L.) Genotypes Under Allahabad Agro-Climate Condition Trends in Biosciences 10(2), Print: ISSN 0974-8431, 629631, 2017.

Rastogi KB, Arya D. (1990). Variability studies in cucumber (Cucumis sativus L.). J Veg.Sci. 1990; 17(2): 224-226.

Richards, L. A. (1954). Diagnosis and improvement of saline and alkaline soils United States Developments Agency Agriculture Hand Book No.60.

Sahni, G.P., Singh, R.K. and Saha, B. C. (1987). Genotypic and phenotypic variability in ridge gourd (Luffa acutangula Roxb.) Indian J. Agril. Sci. 57: 666-688.

Sharma, M. D. and Bhattarai, S. P. (2006). Performance of cucumber cultivars at 
low hill during summer-rainy seasons. J. Inst. Agri. Anim. Sci. 27: 169-171.

Shetty, N. V. and Wehner, T. C. (1998). Evaluation of oriental trellis cucumbers for production in North Carolina. Hort. Sci. 33 (5): 891-896.
Srivastava,V.K. and Srivastava, L.S. (1976). Genetic parameters, correlations coefficients and path coefficient analysis in bitter gourd (Momordica charantia L.). Indian J. Hort. 33 (1): 66-70.

\section{How to cite this article:}

Nagana Boyana Prathyusha and Devi Singh. 2020. Varietal Evaluation Studies in Cucumber under Prayagraj Agro-Climatic Condition (Cucumis sativus L.). Int.J.Curr.Microbiol.App.Sci. 9(11): 454-462. doi: https://doi.org/10.20546/ijcmas.2020.911.056 